the brown rat came in from the plains of Asia. It gradually ousted the black rat from the level places and became the common rat in Britain. It has plenty of sins to its charge, but at least it does not carry plague. Before the War, however, the cellars of London were being made rat-proof, and so it found life difficult. On the other hand, flat roofs, sky-lights, cables, etc., were multiplying, and overhead London became a very suitable habitat for the black rat. So being safe from the brown rat, it was multiplying before the War and was becoming the common rat of London. Should plague break out it might become a menace. As Mr. Hinton says : "If you create a vacancy it is your own very difficult business to fill it".

The independent calculations of Fawcett and of Shantz indicate that something like $6-8$ acres of cultivable land in the world per head of population are available to provide food and raw material. On present yields and practices this area barely suffices. Higher levels of production must be widely attained, and this will mean more and more interference with the mosaic of Nature.

The book will serve a useful purpose in setting out the principles on which rational land utilization must be based if unforeseen and undesirable effects are to be avoided.

E. JoHN Russell.

\section{PRINCIPLES OF EDUCATION}

\section{Education}

Its Data and First Principles. By Sir Percy Nunn. Third edition, revised, and in part rewritten. Pp. 283. (London : Edward Arnold and Co., 1945.) 7s. 6d. net.

$\mathrm{O}^{\mathrm{r}}$ all the late Sir Percy Nunn's numerous and varied writings, this book is the acknowledged masterpiece. Within a comparatively short compass, it reveals his educational doctrine and sets forth the powerful arguments by which he supported it. In a sense it is a summary of his life's work. Published in 1920, and reprinted many times during the ensuing ten years, it reached its second and revised edition in 1930. For this third and, as the sad event has proved, final edition, the author completed the revision himself, and sent the result to England from his enforced exile in Madeira a few weeks before his lamented death.

The previous editions contained fifteen chapters, all of which have been thoroughly revised by him, considerably expanded, and in some places rewritten. A new chapter has been added. The recent remodelling of our school system had made the fundamental problems of education the subject of unprecedented debate and had mado it desirable to treat some old questions more fully, and to give new questions their place in the argument of the book. As the author emphatically declared, however, the central thesis of the book remains unchanged; it maintains as firmly as ever that "the primary aim of all educational effort should be to help boys and girls to achieve the highest degree of individual development of which they are capable". It is good to know that the author lived long enough to see with satisfaction that a widespread acceptance of this idea was a striking, and bade fair to be a permanent, by-product of the war years.

The new chapter to which reference was made above is the tenth in this edition and is entitled "Mental Development". The author's eminent work in the teaching of mathematics enabled him to put the whole matter so simply that any intelligent person can follow the argument, provided he or she is both able and willing to devote the necessary time and trouble. One is left, however, with a lurking suspicion that many teachers and administrators will regard this matter as one for the experts, who are by no means in close agreement even upon fundamental issues. The non-experts will continue to give respect. ful attention to the results of 'intelligence tests', but they will also continue to believe that when scientific analysis has said its last word, they must turn to the whole personality, the living child whose immediate future is being decided. Fortunately, the Act of 1944 puts an end to the absurd practice of making irrevocable decisions about children at the tender age of ten.

T. RAYMONT.

\section{BOTANY IN LATIN AMERICA}

\section{Plants and Plant Science in Latin America}

Edited by Frans Verdoorn. (A New Series of Plant Science Books, Vol. 16.) Pp. xl+384 (38 plates). (Waltham, Mass. : Chronica Botanica Co.; London Wm. Dawson and Sons, Ltd., 1945.) 6 dollars.

\section{$\mathrm{T}$} WIS volume contains a great number of articles dealing with the botany and geology of South America. The botanical contributions cover a wide field including taxonomy, ecology, plant geography, economic botany, cytology and genetics. There are also accounts of rubber culture, fibre plants and a sketch of the geology of the Antilles and a brief account of the general geological features of South America.

The editor has enlisted the aid of eighty-five contributors from South America, the United States and a fow from Europe. The book is divided into two parts, the first of which deals with problems of tropical agriculture, phytogeography of the continent, economic plants, with a special supplement on plant breeding, genetics and cytology. The second part consists of revised articles which have appeared in Chronica Botanica, chiefly on the floras of different regions. Many of these articles are of great interest, such as "The Falkland Islands" by Dr. Scottsberg, and "The Vegetation of Ecuador" by Dr. Svenson, to mention only two out of more than a dozen on phytogeography. A geological sketch of South America is given by Dr. Darrah.

It is impossible in the space of a review to give any detailed impression of this extensive and varied subject-matter; the index alone covers fourteen pages. The arrangement of the articles does not appear to follow any definite plan, so that reference to any subject is not easy; even the longer contributions are restricted to a few pages and merely represent summaries of extensive subjects. Scattered between these are a number of short notes regarding some regional aspect of agriculture or economic botany. A short bibliography to some of the longer articles is a useful feature.

A number of plates taken from various sources embellish the text, and many of the contributions are illustrated by outline maps.

While little detailed information can be obtained from many of the articles owing to their short length, this volume can be recommended as a most valuable general reference book to all botanical and allied subjects in Latin America. 